Al Qalam: Jurnal Ilmiah Keagamaan dan Kemasyarakatan

https://jurnal.stiq-amuntai.ac.id/index.php/al-qalam

P-ISSN: 1907-4174; E-ISSN: 2621-0681

DOI : 10.35931/aq.v16i1. 856

\title{
EKSISTENSI PENDIDIKAN DAN LEMBAGA PENDIDIKAN ISLAM DI INDONESIA PRA DAN PASCA KEMERDEKAAN
}

\author{
Sofyan \\ STAI Darul Arafah Deli Serdang \\ sofyanma543@gmail.com
}

\begin{abstract}
Abstrak
Sejarah pendidikan di Indonesia mengalami pergerakan yang sangat signifikan dari jumlah maupun eksistensinya di masyarakat. Pendidikan tidak hanya dianggap sebagai sebuah keperluan pemenuhan hakhak masyarakat, akan tetapi sudah berkembang menjadi sebuah gaya hidup bagi masyarakatnya. Tujuan dari penelitian ialah agar mengetahuai hadirnya pendidikan dan lembaga pendidikan Islam di Indonesia pra dan pasca kemerdekaan. Penelitian ini menggunakan metode library research dengan jenis penelitian analaisis sejarah. Metode pengumpulan data menggunakan pelacakan sumber literatur sejarah dari buku dan video sejarah pendidikan di Indonesia. Pencarian data menggunakan library research dengan mengumpulkan tulisan yang berkaitan dengan judul ini dari berbagai sumber dan dianalisis dengan content analysis. Hasil penelitian menegaskan bahwa pendidikan Islam pra kemerdekaan dimulai dari pendidikan Islam pada masa Belanda dan Jepang. Pendidikan Islam pasca kemerdekaan meliputi pendidikan Islam era orde lama, orde baru dan era reformasi. Penelitian ini berkontribusi terhadap kajian pendidikan Islam di Indonesia khususnya tentang perkembangan lembaga pendidikan Islam pra dan pasca kemerdekaan.

Kata kunci: Pendidikan Islam, Indonesia, Pra dan Pasca Kemerdekaan
\end{abstract}

\section{PENDAHULUAN}

Pendidikan Islam di Indonesia sudah terdapat semenjak Islam masuk ke Indonesia. Pada permulaan pendidikan Islam hadir dengan hubungan pribadi dan kolektif diantara mubaligh (pengajar) menggunakan muridnya. Kemudian kelompok muslim dibentuk pada kawasan yang ada bangunan masjid menjadi rumah. Masjid sebagai lembaga pendidikan Islam pertama selain rumah kawasan kediaman ulama atau mubaligh.

Menilik sejarah bahwa Indonesia dijajah Belanda selama 350 tahun dijajah Jepang selama 3,5 dan pendidikan pra kemerdekaan berada pada masa dua negara penjajah ini. Pada masa Belanda menguasai Indonesia pendidikan Islam tidak mampu berkembang dengan baik karena Belanda mendiskriminasi pendidikan Islam. Akan tetapi, saat mengambil alih kekuasaan dari pihak Belanda mereka memperbolehkan kepada umat Islam mengembangkan pendidikan. Secara

Al Qalam: Jurnal Ilmiah Keagamaan dan Kemasyarakatan Vol. 16, No. 1 Januari - Juni 2022 
otomatis karena peralihan jajahan maka apa yang menjadi peraturan yang deskriminatif oleh Belanda tidak berlaku lagi pada masa penjajahan Jepang.

Setelah Indonesia merdeka, pendidikan Islam berada pada tiga masa yaitu masa Orde Lama, Orde Baru dan era Reformasi. Pada masa Orde Lama pendidikan Islam belum mendapatkan perhatian yang memadai, karena pada masa ini bangsa Indonesia belum memiliki sistem pemerintahan yang kuat karena baru saja merdeka. Setelah berakhirnya masa Orde Lama pendidikan Islam mengalami kemajuan dan berkembang dengan baik di era Orde Baru. Banyak kemajuan dan kebijakan pemerintah Orde Baru untuk mengembangkan pendidikan Islam.

Pada era reformasi pendidikan Islam lebih diarahkan untuk memantapkan kedudukannya dalam Sistem Pendidikan Nasional. Berbagai kebijakan baru dikeluarkan pada era reformasi yang berbeda dengan sebelumnya. Terjadi dinamika dalam perjalanan pendidikan Islam sebelum dan sesudah Indonesia merdeka. Tulisan ini akan membahas lebih lanjut tentang eksistensi pendidikan Islam pra dan pasca kemerdekaan di Indonesia.

\section{METODE PENELITIAN}

Peneltian ini bagian dari penelitian pustaka (library research) dimana aktivitas penelitian banyak dilakukan di perpustakaan. Untuk mendapatkan data, peneliti mengumpulkan berbagai referensi yang berkaitan dengan pembahasan ini dari berbagai sumber, baik primer maupun sekunder. Data yang telah dikumpulkan kemudian dipaparkan apa adanya sesuai dengan sumber yang diperoleh. Data yang dipaparkan dilakukan secara langsung atau tidak langsung, setelah itu dilakukan pengembangan (generalisasi) dan diakhiri dengan mengambil satu kesimpulan.

\section{HASIL DAN PEMBAHASAN}

\section{Eksistensi Pendidikan dan Lembaga Pendidikan Islam Pra Kemerdekaan}

\section{Pendidikan dan Lembaga pendidikan Islam pada Masa Belanda}

a. Maksud Kedatangan Belanda ke Indonesia

Indonesia dikenal dengan hasil rempah-rempahnya. Karena hasil alam inilah yang menjadi daya tarik kolonial Belanda datang ke Indonesia. Sebelum Belanda masuk dan mejajah Indonesia terlebih dahulu adalah bangsa portugis pada tahun 1511, kemudian disusul dengan Spanyol, Belanda dan Inggris. Awal datangnya penjajah di Indonesia hanya untuk membangun bisnis dagang rempah-rempah, seiring berjalnnya waktu penjajah memonopoli perdagangan tersebut. ${ }^{1}$ Saat itu kaum kolonial belum berani mencampuri problem Islam, dan tidak mempunyai

${ }^{1}$ Ajid Tohir, Perkembangan Peradaban di Kawasan Dunia Islam (Jakarta: PT. Raja Grafindo Persada, 2004), 297.

Al Qalam: Jurnal Ilmiah Keagamaan dan Kemasyarakatan Vol. 16, No. 1 Januari - Juni 2022 
kebijaksanaan terhadap orang Islam sebab belum memiliki pengetahuan tentang Islam dan Bahasa Arab serta jua belum mengetahui sistem sosial Islam. ${ }^{2}$ Tujuan datangnya Belanda ke Indonesia ada tiga yaitu:

1. Agar memperoleh keuntungan ekonomi

2. Agar memperoleh kekuasaan politik dengan cara menguasai wilayah Indonesia

3. Menyebarkan idiologi dan agama. ${ }^{3}$

Belanda datang ke Indonesia dengan tujuan ekonomi sejak tahun 1595 dengan armada kapal dagang sang Perseroan Amsterdam. Kemudian datang lagi angkatan ke 2 pada tahun 1598 yang dipimpin oleh Van Nede, Van Heemskerck dan Van Warwijick. Beberapa kapal dari berbagai kota di Belanda juga ikut datang ke Indonesia. Pada angkatan ke 3 berangkat tahun 1599 dipimpin oleh Van Der Hagen dan terakhir pada angkatan ke 4 pada tahun 1600 dengan pimpinannya Van Neck. ${ }^{4}$ Setelah menguasai aspek ekonomi maka memudahkan pihak kolonial Belanda untuk melaksanakan ide politiknya yaitu menguasai wilayah Indonesia yang memiliki banyak daerah. Dengan ditopang oleh kekuatan ekonominya Belandan pun dapat menjalankan agenda politiknya di Indonesia. ${ }^{5}$

Agenda politik mereka setelah menguasai wilayah dan perekonomian Indonesia dilanjutkan dengan penyebaran agama yang dianut orang-orang Belanda yaitu Kristen. Misi Kristenisasi Belanda dengan strategi mengirim para orientalis ke berbagai daerah nusantara. Dengan dukungan dana, fasilitas yang memadai, mereka mendirikan gereja sebagai sarana mendoktrin ajaran kristiani sekaligus membatasi kegiatan keagamaan Islam yang telah berkembang sebelumnya di Indonesia. $^{6}$

Selain Kristenisasi misi lain yang dilakukan Belanda artinya westernisasi, dengan merubah cara berfikir, berpakaian, menanamkan budaya hidup yang berfoya-foya contoh Barat, dan menanamkan sikap tidak perduli pada bangsa dan tanah air Indonesia. Upaya mendoktrin misi tersebut melalui pendidikan. Ketiga tujuan pada atas terkenal dengan kata 3 (Tri) G yaitu Gold, Gospel dan Glory. Gold secara harfiah mempunyai arti yang sangat indah yaitu emas, hal ini memiliki arti tentang ekonomi. Gospel secara harfiah berarti Injil atau buku kudus yang ada hubungannya dengan penyebaran ajaran Kristen, sedangkan Glory ialah kejayaan. Kejayaan

\footnotetext{
${ }^{2}$ Aqib Suminto, Politik Islam Hindia Belanda (Jakarta: Pustaka LP3ES, 1996), 10.

${ }^{3}$ Abudin Nata, Sejarah Pendidikan Islam (Jakarta: Kencana Prenadamedia Group, 2014),

${ }^{4}$ Nata, 274.

${ }^{5}$ Nata, 278.

${ }^{6}$ Nata, 278 .
} 274.

Al Qalam: Jurnal Ilmiah Keagamaan dan Kemasyarakatan Vol. 16, No. 1 Januari - Juni 2022 
berhubungan dengan penguasaan pada segi politik dan kekuasaan, dimana Indonesia termuat ke dalam bagian daerah kekuasaan pemerintahan Belanda yang masuk dari New Derland. ${ }^{7}$

b. Kondisi Pendidikan Islam

Forum pendidikan Islam di masa Belanda memiliki 3 contoh yaitu contoh forum pendidikan tradisional pesantren yang non-kooperatif serta non akomodatif, pendidikan Islam yang respons kooperatif serta contoh pendidikan yang mengadopsi sistem pendidikan Belanda tanpa memperhatikan nilai-nilai ajaran Islam. ${ }^{8}$ Contoh lembaga pendidikan Islam tradisional pesantren mengambil perilaku anti Belanda sebab Alquran dan Hadis memerintahkan buat memerangi orang-orang kafir, tidak boleh merogoh pimpinan berasal orang kafir dan ditambah lagi perilaku Belanda yang menyengsarakan masyarakat Indonesia. sang sebab itu gerombolan umat Islam dari kalangan pesantren menolak bentuk donasi apapun dari Belanda serta mengharamkan semua produk Belanda.

Kaum santri inilah yang akhirnya berjuang melawan Belanda untuk membebaskan rakyat Indonesia dari penjajah. Dengan semangat jihad yang tinggi sesuai ajaran Islam mereka berjuang mengusir penjajah, namun terbatasnya persenjataan, kurangnya tekhnik berperang dan belum adanya soliditas rakyat Indonesia secara umum maka perjuangan kelompok santri tidak membuahkan hasil yang memuaskan. ${ }^{9}$

Lembaga pendidikan Islam kedua, memiliki sikap kooperatif dan akomodatif terhadap Belanda, tidak menolak atau antipati, tetapi tidak juga terlalu dekat terhadap Belanda. Umat Islam yang kedua ini diwakili oleh kaum modernis seperti Muhammadiyah dan lulusan perguruan tinggi Mesir yang dipengaruhi oleh pemikiran gagasan yang modernis dalam Islam. Menurut kaum modernis umat Islam harus belajar banyak dari Barat supaya cerdas dan memiliki pengetahuan yang luas, untuk itu, sikap umat Islam menjadikan Belanda sebagai mitra yang dapat diajak bekerjasama mendirikan dan mengangkat kualitas pendidikan masyarakat Indonesia dengan mayoritas umat Islam.

Maka berdirilah forum pendidikan dengan menggunakan cara pendidikan Barat akan tetapi ruhnya tetap islami. Mirip Muhammadiyah serta Adabiah School yang dibangun oleh Abdullah Ahmad di Padang yang memperoleh bantuan porto dan tenaga pendidik asal pemerintah Belanda. ${ }^{10}$ kelompok ketiga artinya kelompok umat Islam yang mengambil pendidikan model Barat serta kurang memperhatikan nilai-nilai ajaran Islam sebab ditentukan sang pemikiran

\footnotetext{
${ }^{7}$ Nata, 278.

${ }^{8}$ Nata, 297.

${ }^{9}$ Mahmud Yunus, Sejarah Pendidikan Islam di Indonesia (Jakarta: Mutiara Sumber ilmu, 1995), 134.

${ }^{10}$ Abudin Nata, Pemikiran Para Tokoh Pembaruan Pendidikan Islam di Indonesia (Jakarta: Raja Grafindo Persada, 2008), 46.
}

Al Qalam: Jurnal Ilmiah Keagamaan dan Kemasyarakatan Vol. 16, No. 1 Januari - Juni 2022 
sekularisme Kemal Attatruk pada Turki. Mereka mendirikan forum pendidikan yang diadobsi berasal sistem pendidikan Belanda.

c. Kebijakan Belanda dalam bidang Pendidikan

Pendidikan Islam pada masa Pemerintahan kolonial Belanda tidak dapat berkembang dengan baik karena diskriminasi dari penjajah Belanda. Diskriminasi dilakukan di bidang anggaran, ras, sosial. Menurut Abudin Nata diskriminasi di bidang aggaran terlihat dari perbedaan anggaran 2 kali lipat yang diberikan kolonial Belanda kepada sekolah untuk anak Eropa dari sekolah untuk pribumi. Sebagai contoh pada tahun 1915, siswa di sekolah pribumi sekitar 321.000 orang dan anggaran biaya yang diberikan $f 1.493 .000$, sedangkan sekolah untuk anak-anak Eropa berjumlah 32.000 tetapi anggaran biayanya mencapai $f$ 6.600.000. Ini menunjukkan bahwa Belanda membiarkan strata dan kesenangan berlangsung dalam ketidakberdayaan. ${ }^{11}$

Di bidang sosial diskriminasi terhadap warga negara Indonesia terlihat dari perbedaan sekolah yang didirikan, ada sekolah untuk kaum bangsawan dan sekolah untuk khusus rakyat biasa. Diskriminasi terhadap pendidikan Islam berlanjut dengan kebijakan Belanda membentuk Priesterraden sebagai badan khusus untuk menjadi pengawas kehidupan beragama dan pendidikan Islam.

Atas saran badan ini pemerintah Belanda mengeluarkan beberapa peraturan, antara lain:

1. Pada tahun $1905 \mathrm{M}$ Pengajar atau pengajian harus meminta izin terlebih dahulu.

2. Pada tahun $1925 \mathrm{M}$, peraturan baru dikeluarkan bahwa: pengajar agama Islam dengan sebutan Kyai tidak semua boleh mengajar.

3. Pada tahun $1932 \mathrm{M}$, terbit lagi peraturan tentang hal yang bisa menutup madrasah dan sekolah apabila tidak mendapat izin atau mengajarkan pelajaran yang bertentangan oleh pemerintah.

4. Peraturan netral agama diberlakukan di sekolah umum yang masyoritas siswanya beragama Islam dimaksudkan agar pemerintah tidak memihak kepada satu agama. Pemerintah juga melindungi peribadatan setiap agama ${ }^{12}$

Menurut pandangan Lahmuddin Lubis saat penjajahan Belanda pendidikan agama belum diajarkan di sekolah-sekolah umum, namun di tingkat perguruan tinggi tepatnya di Fakultas Hukum mahasiswa diajari dengan mata kuliah Islamologi yaitu pemahaman tentang Islam. Walaupun pendidikan agama tidak diajarkan secara resmi akan tetapi para muballigh/guru agama mengambil waktu setelah berakhirnya jam-jam pelajaran atau pada waktu sore setiap hari Minggu atau Jum'at untuk mengajar agama. Mereka berceramah dihadapan para siswa dari sekolah-

${ }^{11}$ Abudin Nata, Kapita Selekta Pendidikan Islam, vol. 2 (Bandung: Angkasa, 2003), 145.

${ }^{12}$ Zuhairini, Sejarah Pendidikan Islam (Jakarta: Bumi Aksara, 1992), 149-50.

Al Qalam: Jurnal Ilmiah Keagamaan dan Kemasyarakatan Vol. 16, No. 1 Januari - Juni 2022 
sekolah umum seperti di MULO (lembaga pendidikan setingkat SMP), AMS (setingkat SMA) atau Kweekschool (sekolah guru). ${ }^{13}$

\section{Pendidikan dan Lembaga Pendidikan Islam pada Masa Jepang}

a. Jepang masuk ke Indonesia

Jepang masuk ke Indonesia saat dunia mengalami Perang Dunia 2, dengan dasar untuk perluasan wilayah dan ingin menguasai sumber ekonomi. Jepang membawa jargon Asia Timur Raya untuk Asia Semboyan Baru untuk menguasai Indonesia. ${ }^{14}$

Sebelum masuk ke Indonesia Jepang sudah mempelajari karakter masyarakat pribumi serta agama yang dianut, kemudian Jepang memberikan perhatian khusus terhadap agama mayoritas yaitu Islam. Hal yang diberikan Jepang untuk mengambil simpatik seperti menerbitkan jurnal dengan bahasa Arab agar bisa disebarkan hingga ke luar negeri. Memberikan penghormatan kepada Indonesia sebagai saudara tua di Asia Timur Raya. Sehingga Jepang masuk ke Indonesia tidak mendapatkan kesulitan. ${ }^{15}$

b. Kebijakan pemerintah Jepang untuk pendidikan Islam

Lembaga pendidikan dan sistem pendidikan Islam pada masa Jepang tidak jauh berbeda dengan sistem pendidikan Islam pada masa Belanda, lembaga pendidikan Islam yang ada antara lain pesantren, dan lembaga pendidikan Belanda yang muatannya terdapat pelajaran agama. Ditinjau dari aspek pelaksanaan pendidikan Islam, maka pada masa Jepang umat Islam dapat lebih leluasa mengembangkan pendidikan. Peraturan-peraturan yang diskriminatif pada masa Belanda tidak diberlakukan lagi pada masa Jepang.

Sekitar 3,5 tahun Jepang menguasai Indonesia, terdapat beberapa kebijakan-kebijakan yang dilakukan pemerintah Jepang berkaitan dengan pendidikan Islam yang sangat menguntungkan. Jepang ingin menunjukkan bahwa mereka memberikan perhatian serta kebebasan bagi kaum Muslimin. Menurut Harri J. Benda kebijakan tersebut antara lain:

1. Berdirinya Shumuba dan Shumuka yaitu Kantor Urusan Agama Tingkat Provinsi (Kanwil Agama) dan Kantor Urusan Agama Tingkat Pusat (Departemen Agama) yang mengatur dan mengurusi berbagai hal yang berkaitan dengan masalah keagamaan. ${ }^{16}$

2. Jepang mendirikan lembaga dengan fungsi agar bisa menyampaikan ide, aspirasi dan pemikiran dari kalangan umat Islam dan organisasi keagamaan untuk saling berkomunikasi,

\footnotetext{
${ }^{13}$ Lahmuddin Lubis, Pendidikan Agama Dalam Perspektif Islam, Kristen dan Budha (Bandung: Citapustaka Media, 2013), 3-4.

${ }^{14}$ Lubis, 151.

${ }^{15}$ Nata, Sejarah Pendidikan Islam, 303.

${ }^{16}$ Daniel Dhakidae, Bulan Sabit dan Matahari Terbit Islam Indonesia pada Masa Pendudukan Jepang (Jakarta: Dunia Pustaka Jaya, 1985), 133.
}

Al Qalam: Jurnal Ilmiah Keagamaan dan Kemasyarakatan Vol. 16, No. 1 Januari - Juni 2022 
bersilaturrahmi dan berdiskusi berkaitan dengan keagamaan. Lembaga tersebut diberi nama Majlis Islam A'la Indonesia (MIAI). ${ }^{17}$

3. Para ulama Muslim bekerjasama dengan pemimpin-pemimpin yang nasionalis diizinkan membentuk barisan Pembela Tanah Air (PETA). Santri dan pemuda Muslim ikut dalam latihan kader militer ini, yang akhirnya menjadi cikal bakal Tentara Nasional Indonesia sekarang. ${ }^{18}$

4. Jepang meyakinkan Indonesia bahwa mereka tidak bermaksud menjajah bangsa Indonesia dengan cara mendirikan Badan Penyelidik Usaha Persiapan Kemerdekaan Indonesia (BPUPKI) dan mendirikan Panitia Persiapan Kemerdekaan Indonesia (PPKI).

Kebaikan-kebaikan yang ditawarkan Jepang kepada Indonesia ternyata hanya sebuah taktik dan strategi agar bisa menggandeng dan mencari simpatisan bangsa Indonesia dalam menghadapi Perang Dunia II. Jepang menunjukkan sifat penjajah tatkala mengalami kekalahan dari tentara sekutu yang terdiri dari Amerika, Inggris, Perancis dan Australia. Guna memperoleh dukungan SDM dan logistik pemerintah Jepang menuntut rakyat Indonesia untuk melakukan tanam paksa atau kerja rodi dan menghukum rakyat Indonesia yang tidak mematuhi perintah mereka dengan hukuman mati. Kemerdekaan yang dijanjikan Jepang hanya tipu daya mereka saja dan rakyat Indonesia semakin tertindas dan mengalami penderitaan lahir dan batin. Penderitaan rakyat Indonesia berakhir ketika Hiroshima dan Nagasaki dihancurkan oleh Amerika dengan bom atom. ${ }^{19}$

\section{Pendidikan dan Lembaga Pendidikan Islam Pasca Kemerdekaan}

\section{Pendidikan Islam pada Zaman Orde Lama}

a. Pengertian Orde Lama

Orde diartikan dengan zaman, secara kontekstual orde lama mengandung arti zaman pada saat Presiden Soekarno berkuasa sejak tahun 1945 sampai digantikan oleh Presiden Soeharto tahun 1965 melalui Surat Perintah 11 Maret 1966 yang dikenal dengan Supersemar. Pada masa ini bangsa Indonesia baru saja terlepas dari cengkraman penjajah setelah dikuasai kolonial Belanda (350 tahun) dan Jepang (3,5 tahun). Sebagai negara yang baru merdeka bangsa Indonesia masih mencari bentuk dan jati diri untuk menjadi negara Republik yang kuat pondasinya.

b. Islam masa Orde Lama

Kondisi negara yang baru merdeka dan belum memiliki landasan yang kuat menjadikan pendidikan Islam pada masa Orde Lama belum diperhatikan secara baik. Menurut Karel A. Stenbrink hal pertama yang dilakukan pemerintah untuk mengelola pendidikan Islam dengan

\footnotetext{
${ }^{17}$ Dhakidae, 144.

${ }^{18}$ Zuhairini, Sejarah Pendidikan Islam, 151.

${ }^{19}$ Nata, Sejarah Pendidikan Islam, 307.
}

Al Qalam: Jurnal Ilmiah Keagamaan dan Kemasyarakatan Vol. 16, No. 1 Januari - Juni 2022 
mendirikan Depertemen Agama untuk membina pendidikan agama secara formal institusional. ${ }^{20}$ Departemen Agama sudah ada sejak kolonial Belanda yang disebut dengan Kantor Voor Inlandshe Zaken dan pada masa Jepang disebut dengan Shumuka. Setelah Indonesia merdeka pada tanggal 3 Januari 1945 dirubah menjadi Kementrian Agama. Di sisi lain pemerintah Orde Lama juga mendirikan Kementrian Pendidikan dan Kebudayaan sehingga terjadilah dualisme pendidikan di Indonesia yaitu pendidikan agama dan pendidikan umum. ${ }^{21}$

Untuk mengatur pelaksanaan pendidikan agama pada sekolah-sekolah umum negeri dan swasta yang berada di bawah Kementrian Pendidikan dan Kebudayaan pada tahun 1946 dikeluarkanlah Surat Keputusan Bersama (SKB) antara Menteri P dan K dengan Menteri Agama. Pendidikan agama diatur secara khusus dalam Undang-Undang Nomor 4 Tahun 1950 Bab XII pasal 20. "UU Nomor 4 Tahun 1950 Bab XII Pasal 20 menegaskan: 1) Dalam sekolahsekolah negeri diadakan pelajaran agama, orang tua murid menetapkan apakah anaknya akan mengikuti pelajaran tersebut, 2) Cara penyelenggaraan pengajaran agama di sekolah-sekolah negeri diatur dalam peraturan yang ditetapkan oleh Menteri Pendidikan Pengajaran dan Kebudayaan bersama-sama dengan Menteri Agama”.

Menurut Hasbullah pemerintah Orde Lama memberikan perhatian kepada urusan pendidikan agama yang diatur juga melalui Keputusan Sidang MPRS di bulan Desember 1960. Menyatakan: " dalam rangka melaksanakan Manipol Usdek di bidang mental/agama dengan syarat spiritual dan mental agar setiap warga negara dapat mengembangkan kepribadian dan kebangsaan Indonesia serta menolak pengaruh buruj budaya asing. Pada pasal 3 ditegaskan bahwa agama menjadi mata pelajaran di sekolah umum, mulai dari sekolah dasar hingga perguruan tinggi dengan satu ketentuan bahwa seorang murid berhak ikut serta dalam pendidikan agama jika wali murid tidak menyatakan keberatan. ${ }^{22}$

Pada masa Orde Lama ditetapkan kebijakan tentang program-program pendidikan dan macam-macam pendidikan dan pengajaran islam, antara lain:

1. Pesantren yaitu sekolah swasta keagamaan yang memiliki asrama atau pondok, kyai, kitab kuning, masjid, santri.

2. Madrasah Diniyah yaitu sekolah yang memberikan pelajaran tambahan bagi murid sekolah negeri yang usianya 7-20 tahun. Pelajaran diberikan di dalam kelas kira-kira sepuluh jam seminggu di waktu sore.

\footnotetext{
${ }^{20}$ Karel A Stenbrink, Pesantren, Madrasah, Sekolah, cek. 2 (Jakarta: LP3ES, 1994), 62.

${ }^{21}$ Enung K Rukiati dan Fenti Hikmawati, Sejarah Pendidikan Islam di Indonesia (Bandung: Pustaka Setia, 2006), 68.

${ }^{22}$ Hasbullah, Sejarah Pendidikan Islam di Indonesia, cet. 5 (Jakarta: Rajawali Press, 1995), 77.

Al Qalam: Jurnal Ilmiah Keagamaan dan Kemasyarakatan Vol. 16, No. 1 Januari - Juni 2022
} 
3. Madrasah-madrasah swasta yaitu pesantren yang di kelola secara modern yang bersamaan dengan pengajaran agama juga pelajaran umum. Kurikulumnya 60-65\% pelajaran umum dan $35-40 \%$ untuk pelajaran agama.

4. Madrasah Ibtidaiyah Negeri (MIN) yaitu sekolah dasar negeri enam tahun, perbandingan umumnya kira-kira 1:2. Pendidikan selanjutnya dapat melanjutkan ke MTsN.

5. Pendidikan Teologi Tertinggi pada tingkat universitas seperti IAIN yang didirikan pada tahun $1960 .{ }^{23}$

Pada masa ini pesantren dan madrasah berkembang dengan pesat, bahkan pada masa Orde Lama muncul lembaga pendidikan Islam baru yang tidak ada sebelumnya antara lain Pendidikan Guru Agama (PGA), Pendidikan Hakim Islam Negeri (PHIN), Madrasah Wajib Belajar (MWB). ${ }^{24}$

\section{Pendidikan Islam Masa Orde Baru}

a. Pengertian Orde Baru

Orde Baru muncul setelah Orde Lama mengakhiri kekuasaannya yang dianggap telah melakukan penyelewangan terhadap Undang-undang Dasar 1945 dan Pancasila. Pemerintahan Orde Lama pada masa Soekarno dituduh telah mengganti UUD 1945 dan mengganti Pancasila dengan Nasakom (Nasionalis Agama dan komunis). Beliau juga dinyatakan terlibat dalam Gerakan 30 September Partai Komunis Indonesia (G 30 S PKI) yang telah menewaskan 7 orang Jenderal dan 1 orang puteri Jenderal Abdul Haris Nasution. Fakta di atas menjadi alasan untuk mengganti Presiden Soekarno dengan Presiden Soeharto melalui Surat Perintah 11 Maret (Supersemar) 1966. Mulai tahun 1966 beralihlah dari zaman Orde Lama ke zaman Orde Baru.

b. Pendidikan Islam era Orde Baru

Pendidikan Islam pada masa Orde Baru banyak mengalami kemajuan dan perkembangan, kendati belum memuaskan masyarakat Muslim Indonesia. Berbagai kebijakan dan perubahan dilakukan oleh pemerintah Orde Baru untuk memajukan pendidikan Islam, antara lain:

1. Pendidikan Islam dimasukkan ke dalam Sistem Pendidikan Nasional, hal ini ditandai dengan lahirnya Undang-undang Nomor 2 Tahun 1989 yang menjadi wadah formal terintegrasinya pendidikan Islam dalam Sistem Pendidikan Nasional. Menurut Haidar Putra Daulay pendidikan Islam mendapat peluang untuk berkembang setelah terintegrasi dalam Sistem Pendidikan Nasional dapat diklasifikasikan kepada tiga hal, antara lain:

a. Pendidikan Islam sebagai lembaga pendidikan formal terdapat pada pasal 17, 18, 20. Sebagai lembaga pendidikan non formal pasal 26, informal 27, Pendidikan Usia Dini pasal 28, dan pendidikan keagamaan pasal 30.

${ }^{23} \mathrm{~K}$ Rukiati dan Hikmawati, Sejarah Pendidikan Islam di Indonesia, 70.

${ }^{24}$ Maksum, Madrasah: Sejarah dan Perkembangannya (Jakarta: Logos Wacana Ilmu, 2013), 122.

Al Qalam: Jurnal Ilmiah Keagamaan dan Kemasyarakatan Vol. 16, No. 1 Januari - Juni 2022 
b. Pendidikan Islam sebagai mata pelajaran menjelaskan bahwa kurikulum pendidikan Islam diarahkan untuk meningkatkan iman dan taqwa, meningkatkan akhlak mulia, keragaman potensi daerah dan lingkungan.

c. Nilai-nilai Islami dalam UU No.20 Tahun 2003, inti dari hakekat nilai-nilai Islami adalah nilai yang membawa kemaslahatan dan kesejahteraan bagi seluruh makhluk, demokratis, egalitarian dan humanis. ${ }^{25}$

2. Pendidikan Islam yang berciri khas pesantren dan madrasah mengalami perubahan dan modernisasi yang bersifat fisik dan non fisik, modernisasi pada aspek kurikulum, pengembangan kelembagaan, manajemen pengelolaan dan sumber daya manusia serta peningkatan mutu pendidikan Islam. Pada masa Orde Baru banyak bermunculan lembaga pendidikan Islam non formal seperti Majelis Taklim yang tergabung dalam BKMT (Badan Kontak Majelis Taklim). Pada masa ini banyak juga berdiri lembaga keuangan seperti Bank Muamalat Indonesia, penerbitan seperti Harian Umum Republika, lembaga sosial seperti Ikatan Cendikiawan Muslim Indonesia (ICMI), Bayt Alquran, Festival Istiqlal dan peradilan yang islami di antaranya Undang-undang Peradilan Agama. ${ }^{26}$

Berkembangnya pendidikan Islam pada masa Orde Baru disebabkan tiga hal yaitu:

a. Terjadinya hubungan yang baik antara pemerintah dengan umat Islam setelah enam belas tahun sejak Presiden Soeharto berkuasa.

b. Perekonomian nasional tumbuh dengan baik mencapai $7 \%$.

c. Pada zaman Orde Baru Indonesia termasuk negara yang aman dan stabil di kawasan Asia Tenggara. Munculnya institusi baru pada masa Orde baru seperti terbentuknya Majelis Ulama Indonesia (MUI) tahun 1975, munculnya Ikatan Cendikiawan Muslim Indonesia (ICMI) tahun 1990, lahirnya Bank Muamalat Indonesia (BMI) tahun 1991 menggambarkan perkembangan dan kemajuan Islam pada masa Orde Baru. ${ }^{27}$

\section{Pendidikan Islam pada Masa Reformasi}

\section{a. Pengertian Reformasi}

Reformasi diartikan dengan membentuk atau menata kembali sesuatu yang kacau balau dengan cara mengurangi, memperbaharui atau mengganti. Dalam konteks ke-Indonesaan zaman atau era reformasi diawali dari jatuhnya rezim Orde Baru masa Presiden Soeharto pada tahun 1998 sampai sekarang. Jatuhnya Presiden Soeharto disebabkan pemerintah dianggap tidak mampu membawa Indonesia ke arah yang aman, damai, tertib dan sejahtera serta demokratis. Pemerintah

${ }^{25}$ Haidar Putra Daulay, Pendidikan Islam dalam Sistem Pendidikan Nasional di Indonesia (Jakarta: Prenada Media, 2004), 13-16.

${ }^{26}$ Nata, Sejarah Pendidikan Islam, 341.

${ }^{27}$ Sudirman Teba, Islam Orde Baru, Perubahan Politik dan Keagamaan (Yogyakarta: Tiara Wacana Yogya, 1993), xv.

Al Qalam: Jurnal Ilmiah Keagamaan dan Kemasyarakatan Vol. 16, No. 1 Januari - Juni 2022 
Orde Baru diyakini membiarkan serta melakukan praktek KKN (Korupsi, Kolusi dan Nepotisme), memiliki hutang luar negeri yang banyak serta membiarkan pihak asing dan aseng menguasai Indonesia. Puncaknya beliau harus lengser dan menyerahkan kekuasaan kepada Presiden Habibi setelah terjadi demonstrasi besar-besaran yang menolak Presiden melanjutkan kepemimpinannya.

Pemerintah pada masa Reformasi memiliki fungsi untuk memperbaiki, melakukan koreksian dan penyempurnaan secara menyeluruh terhadap kinerja pemerintah pada masa Orde Baru dari semua aspek, politik, ekonomi, keamanan, sosial, budaya, pendidikan, kesehatan agar lebih demokratis, adil, akuntabel, transparan bertanggungjawab untuk mewujudkan masyarakat Indonesia yang adil, makmur dan sejahtera.

b. Keadaan Pendidikan Islam di Zaman Reformasi

Sesuai tujuan dari reformasi yaitu memperbaiki, mengoreksi dan melakukan penyempurnaan maka pendidikan Islam pada masa Reformasi mengalami perubahan dan keadaannya lebih baik dari masa Orde Baru. Menurut Abudin Nata beberapa perubahan yang positif bagi kemajuan pendidikan Islam, antara lain: ${ }^{28}$

1. Menguatkan dan memantapkan kedudukan pendidikan Islam dalam Sistem Pendidikan Nasional dengan mengganti Undang-undang Nomor 2 Tahun 1989 menjadi Undangundang Nomor 20 Tahun 2003 "Dalam Undang-undang Nomor 2 Tahun 1989 pendidikan Islam hanya madrasahlah yang termasuk dalam sistem pendidikan nasional, setelah dirubah menjadi UU Nomor 20 Tahun 2003 pendidikan"

2. Terjadi peningkatan anggaran pendidikan Islam dengan ditetapkannya anggaran pendidikan sebesar 20\% dari Anggaran Pendapatan dan Belanja Negara (APBN).

3. Ditetapkannya program wajib belajar sembilan tahun bagi anak-anak Indonesia yang diberlakukan pada lembaga pendidikan di bawah Kementrian Agama dan Kementrian Pendidikan Nasional.

4. Pemerintah pada zaman reformasi membuka lembaga pendidikan bertaraf nasional (SBN) dan lembaga pendidikan yang bertaraf internasional (SBI).

5. Diberlakukannya sertifikasi bagi guru dan dosen yang mengajar di negeri dan swasta yang diatur dalam PP Nomor 74 Tahun 2005 tentang Sertifikasi Guru dan Dosen.

6. Melakukan pengembangan kurikulum dari Kurikulum Berbasis Kompetensi Tahun 2004 ke kurikulum KTSP Tahun 2006 dan kurikulum K 13.

7. Melaksanakan pengembangan pendekatan pembelajaran yang berpusat pada murid melalui kegiatan pembelajaran yang Paikem (partisipatif, inovatif, aktif, kreatif, efektif dan menyenangkan).

\footnotetext{
${ }^{28}$ Nata, Sejarah Pendidikan Islam, 352-55.
}

Al Qalam: Jurnal Ilmiah Keagamaan dan Kemasyarakatan Vol. 16, No. 1 Januari - Juni 2022 
Melihat beberapa kebijakan yang berkaitan dengan pelaksanaan pendidikan pada masa reformasi sebagaimana disebutkan di atas dapat disimpulkan bahwa pendidikan pada era reformasi jauh lebih baik dan maju dari masa Orde Lama dan Orde Baru. Pemerintah terus memperbaiki sistem pendidikan nasional dengan cara membaurnya dari segi hukum, anggaran, dan SDM. Walaupun masih banyak terasa kekurangan di sana sini namun upaya untuk memperbaiki kualitas pendidikan di zaman reformasi Indonesia terus dilakukan secara berkala.

\section{KESIMPULAN}

Belanda datang ke Indonesia dengan 3 kepentingan yaitu ekonomi, kekuasaan dan penyebaran agama Kristen yang terkenal dengan tiga G (gold, glorius dan gospel). Indonesia dijajah oleh Belanda selama 350 tahun, dengan lamanya masa jajahan itu membuat bangsa pribumi menderita, Belanda terus mengeruk dan memeras hasil alam nusantara. Tak hanya itu saja, Belanda juga menjadikan budak masyarakat pribumi dan terus meperbodohi bangsa Indonesia. Tak anyal berpengaruh kepada pendidikan Islam saat itu, di mana kebijakan Kolonial Belanda yang berpihak (diskriminatif).

Setelah berakhirnya kekuasaan Belanda, Jepang menjajah Indonesia. Hadirnya Jepang ke Indonesia tidak mengalami kendala dikrenakan Jepang sudah mempelajari karakter bangsa Indonesia serta agama yang banyak dipercayai (dianut). Oleh sebab itu, Jepang mengambil metode persahabatan dengan memberikan keluasan agar Islam bisa berkembang.

Setelah berakhirnya era kolonial bangsa Indonesia memasuki masa Orde Lama, pendidikan Islam pada masa ini jauh berbeda dengan keadaan pada masa penjajahan Belanda dan Jepang. Pendidikan Islam tidak hanya diajarkan dan pesantren dan madrasah saja tetapi diajarkan juga di sekolah umum sesuai Surat Keputusan Bersama (SKB) antara Kementrian Agama dan Kementrian Pendidikan dan Kebudayaan. Pada masa ini berdiri lembaga pedidikan Islam yang tidak ada sebelumnya seperti Pendidikan Guru Agama (PGA), Pendidikan Hakim Islam Negeri (PHIN), Madrasah Wajib Belajar (MWB).

Pada masa Orde Baru pemerintah memusatkan perhatian utamanya pada pembangunan ekonomi dan pendidikan Islam pada masa ini jauh lebih maju dan berkembang. Pendidikan Islam telah masuk pada Sistem Pendidikan Nasional, madrasah dan pesantren mengalami modernisasi dan perubahan yang bersifat fisik dan non fisik, terjadi pengembangan kurikulum, manajemen pengelolaan dan sumber daya manusia. Hal yang paling penting untuk dicatat perkembangan pendidikan Islam terjadi karena adanya hubungan yang baik antara pemerintah dan umat Islam.

Setelah berakhirnya masa Orde Baru bangsa Indonesia berada di era reformasi, era reformasi lahir untuk mengadakan perbaikan, koreksi dan penyempurnaan dari berbagai kebijakan

Al Qalam: Jurnal Ilmiah Keagamaan dan Kemasyarakatan Vol. 16, No. 1 Januari - Juni 2022 
yang telah dikeluarkan era sebelumnya dalam bidang politik, pendidikan, ekonomi, budaya dan lain-lain. Pada masa reformasi kebijakan yang berkaitan dengan pendidikan antara lain merubah UU No 2 tahun 1989 menjadi UU No 20 Tahun 2003, peningkatan anggaran pendidikan dari 5\% menjadi $20 \%$.

\section{DAFTAR PUSTAKA}

A Stenbrink, Karel. Pesantren, Madrasah, Sekolah. Vol. 2. Jakarta: LP3ES, 1994.

Dhakidae, Daniel. Bulan Sabit dan Matahari Terbit Islam Indonesia pada Masa Pendudukan Jepang. Jakarta: Dunia Pustaka Jaya, 1985.

Hasbullah. Sejarah Pendidikan Islam di Indonesia. cet. 5. Jakarta: Rajawali Press, 1995.

K Rukiati, Enung, dan Fenti Hikmawati. Sejarah Pendidikan Islam di Indonesia. Bandung: Pustaka Setia, 2006.

Lubis, Lahmuddin. Pendidikan Agama dalam Perspektif Islam, Kristen dan Budha. Bandung: Citapustaka Media, 2013.

Maksum. Madrasah: Sejarah dan Perkembangannya. Jakarta: Logos Wacana Ilmu, 2013.

Nata, Abudin. Kapita Selekta Pendidikan Islam. cet. 2. Bandung: Angkasa, 2003.

- Pemikiran Para Tokoh Pembaruan Pendidikan Islam di Indonesia. Jakarta: Raja Grafindo Persada, 2008.

—. Sejarah Pendidikan Islam. Jakarta: Kencana Prenadamedia Group, 2014.

Putra Daulay, Haidar. Pendidikan Islam dalam Sistem Pendidikan Nasional di Indonesia. Jakarta: Prenada Media, 2004.

Suminto, Aqib. Politik Islam Hindia Belanda. Jakarta: Pustaka LP3ES, 1996.

Teba, Sudirman. Islam Orde Baru, Perubahan Politik dan Keagamaan. Yogyakarta: Tiara Wacana Yogya, 1993.

Tohir, Ajid. Perkembangan Peradaban di Kawasan Dunia Islam. Jakarta: PT. Raja Grafindo Persada, 2004.

Yunus, Mahmud. Sejarah Pendidikan Islam di Indonesia. Jakarta: Mutiara Sumber ilmu, 1995.

Zuhairini. Sejarah Pendidikan Islam. Jakarta: Bumi Aksara, 1992.

Al Qalam: Jurnal Ilmiah Keagamaan dan Kemasyarakatan Vol. 16, No. 1

Januari - Juni 2022 